\title{
A Lieu Sûr for the Fenians: France, the Fenians and the Irish Colony, 1848-1870
}

Un « lieu sûr » pour les Fenians : France, les Fenians et la Colonie irlandaise, 1848-1870

\section{Luke William Watson}

\section{(2) OpenEdition}

\section{Journals}

Electronic version

URL: https://journals.openedition.org/etudesirlandaises/11652

DOI: 10.4000/etudesirlandaises. 11652

ISSN: 2259-8863

Publisher

Presses universitaires de Caen

\section{Printed version}

Date of publication: 30 December 2021

Number of pages: $25-42$

ISBN: 978-2-84133-157-0

ISSN: 0183-973X

\section{Electronic reference}

Luke William Watson, "A Lieu Sûr for the Fenians: France, the Fenians and the Irish Colony, 1848-1870", Études irlandaises [Online], 46-2 | 2021, Online since 17 December 2021, connection on 03 November 2022. URL: http://journals.openedition.org/etudesirlandaises/11652 ; DOI: https://doi.org/10.4000/ etudesirlandaises. 11652

\section{(c) (i) (ㅇ)}

Creative Commons - Attribution-NonCommercial-ShareAlike 4.0 International - CC BY-NC-SA 4.0 https://creativecommons.org/licenses/by-nc-sa/4.0/ 


\title{
A Lieu Sûr for the Fenians: France, the Fenians and the Irish Colony, 1848-1870
}

\begin{abstract}
Every significant Irish nationalist organisation has depended on the international support of the Irish diaspora, never more so than in the $19^{\text {th }}$ century. The Young Irelanders were scattered abroad in so many instances after the failure of the 1848 Rebellion, with many of their number fleeing to America, continental Europe and elsewhere. Though the Franco-Irish dimension of the Fenian movement is smaller in scale than Irish-American dimension, it is nonetheless worthy of investigation. This article seeks to address the lack of emphasis placed on the French element of Irish nationalism by providing a thorough examination of the influence of $19^{\text {th }}$-century France on the Fenians. It charts the direct influence of Paris and of the Irish diaspora in France on the movement and its exposure to organisations such as Young Italy, Young Poland and native French movements including La Société des Saisons. This paper concludes that France, French revolutionary spirit and French republican ideals were of significant importance to the Fenian movement, and played a direct role in shaping the development of Irish nationalism.
\end{abstract}

Keywords: Fenianism, France, Ireland, Irish Republican Brotherhood, La Société des Saisons - Paris, Young Europe, Young Italy, Young Poland.

Résumé: Toutes les organisations nationalistes irlandaises majeures ont été dépendantes $d u$ soutien international de la diaspora irlandaise, et ce fut particulièrement vrai au XIX ${ }^{e}$ siècle. Nombre des Young Irelanders se trouvèrent dispersés à l'étranger, en Amérique, en Europe continentale ou ailleurs, après l'échec de la rébellion de 1848. Bien que la dimension francoirlandaise du mouvement fenian soit plus modeste que sa dimension irlando-américaine, elle reste digne d'examen. Dans un souci de rééquilibrage, le présent article cherche à mettre l'accent sur l'élément français du nationalisme irlandais par un examen approfondi de l'influence de la France du XIX e siècle sur les Fenians. Il retrace l'influence directe de Paris et de la diaspora irlandaise en France sur le mouvement et ses liens avec des organisations telles que la Jeune Italie, la Jeune Pologne et des mouvements français tels que la Société des Saisons. L'article en conclut que la France, l'esprit révolutionnaire français et les idéaux républicains français ont eu une importance significative pour le mouvement fenian et ont joué un rôle direct dans le développement du nationalisme irlandais.

Mots clés: fenianisme, France, Irlande, Fraternité républicaine irlandaise, Société des Saisons, Jeune Europe, Jeune Italie, Jeune Pologne.

\section{Introduction}

The $19^{\text {th }}$ century was a highly dynamic century where revolution in Europe is concerned. Even before the February Revolution, uprisings were commonplace across the continent, with frequently dramatic results. Many of these movements 
were not successful, and often their revolutions were crushed quite forcefully. At the same time, however, the failure did little to dampen the commitment and idealism which fueled the revolutionaries, and the $19^{\text {th }}$ century saw crowds of exiles fleeing their home countries to establish diaspora communities in foreign lands. Ireland was no exception, and its brand of advanced revolutionary nationalism which emerged in the decades after the failure of the 1848 Young Irelander Rebellion, Fenianism, eventually spread across the globe in the footsteps of the Irish diaspora. ${ }^{1}$ Although it was a movement aimed at Irish liberation, Fenianism was located outside of Ireland for much of its existence, as it was formed primarily within the exiled Irish diaspora. In many cases, the most prominent Fenians were part of the Irish-American diaspora, who had been forced to flee Ireland either because of the Famine or because of legally imposed exile. However, in tandem to this American diaspora community, there was a small and yet highly active Irish exile community to be found in Paris, the revolutionary heartland of Europe.

France was a symbol of liberty for Irish republicans in the $19^{\text {th }}$ century, harking back to the United Irishmen who had brought a French army to Ireland in $1798 .^{2}$ As in the century before, France's capital offered Irish nationalists a chance to continue their revolutionary project in safety. The Fenians who found themselves in Paris, whether direct exiles or not, were safe from the reach of the British Empire in the city's "pensions" and boarding houses. There they could collude, plan and organise in close contact with the movement at home in Ireland and abroad in the United States. Furthermore, France at this time was alive with revolutionary energy, and Paris was the city to which revolutionary exiles from almost every European revolutionary society fled. Among others, it housed revolutionaries from various Italian and Polish nationalist groups who lived alongside local French activists. ${ }^{3}$ These societies offered the would-be Fenians a chance to learn and perfect their craft, and their influence can be seen throughout the Fenian movement, most profoundly in the ethos and organisation of the Irish Republican Brotherhood (IRB). ${ }^{4}$ Behind all this was the so-called "Irish Colony", a community

1. Cian MacMahon, The Global Dimensions of Irish Identity: Race Nation, and the Popular Press, 1840-1880, Chapel Hill, University of North Carolina Press, 2015, p. 6-10; MacMahon principally discusses the spread of the Young Irelanders through the diaspora following 1848, but nonetheless this text serves as a good overview of the transnational elements of Irish nationalism.

2. Janick Julienne discusses further the importance of France to Ireland, especially in the $19^{\text {th }}$ century. See Janick Julienne, "La France et l'Irlande nationaliste de 1860 à 1890: évolution et mutation de liens multiséculaires”, Études irlandaises, no. 24-1, 1999, p. 123-124, online: https://www.persee. fr/doc/irlan_0183-973x_1999_num_24_1_1487; Matthew Kelly, "Languages of Radicalism, Race, and Religion in Irish Nationalism: The French Affinity, 1848-1871", Journal of British Studies, vol. 49 , no. 4, 2010, p. 803, 805 .

3. The groups of particular concern for this paper include Young Italy and Young Poland, as well as the French societies La Société des Familles and La Société des Saisons.

4. Fenianism itself was first given official expression by James Stephens with the founding of the Irish Republican Brotherhood in Dublin in 1858, and was then shortly joined by the Fenian Brotherhood, founded in America by John O'Mahony. However, "Fenian" is used here to refer to the individuals directly involved with Fenianism in the latter half of the $19^{\text {th }}$ century. Notably, it includes those survivors of the Young Irelander Rebellion of 1848 who sowed the seeds for 
of Irish diaspora members in the heart of France: writers, journalists, artists and veterans - both those descended from Irish immigrants from decades prior and recent émigrés. Though small, the Irish Colony was very politically charged, and played an active role in aiding the Fenians and other Irish nationalists who found themselves in the French capital. ${ }^{5}$

Paris, and by extension France as a whole, was highly significant to the wider Fenian movement, and had a profound impact on the members of that society who found themselves in exile there. Alongside America and Britain, France had a distinct role to play in shaping advanced Irish nationalist politics, and in enabling the operation of the movements that gave it expression. The Paris that the Fenians found themselves in throughout the 1850s and 1860s was one that was at the heart of European international politics and, as a result, central to continental conspiracy. It was a place where the Fenians could seek to learn the trade of organising a secret society, and a city which, particularly through the Irish Colony, could encourage and advance their nationalist and revolutionary sentiments. While it is generally understood that James Stephens, John O’Mahony and others in the Fenian movement learnt a great deal from their exile in Paris, the specifics of their exile and how exactly they were influenced is often left unclear. ${ }^{6}$ This article seeks to address this lacuna in the literature. It will assess the impact of the European context on the Fenian movement, and in particular its impact on their operations in France. It will also analyse the involvement of the Irish Colony with Irish nationalist movements in France, demonstrating the distinct

Fenianism in the 1850 s and would go to be prominent in the movement later, even though at this time the Fenian movement had not yet been officially formed.

5. The phrase "the Irish Colony" is at best vague, but it is generally taken to refer to the Irish community in Paris, especially the Bohemian and politically active members of the Irish diaspora. In his contemporary reflections, for example, John Augustus O'Shea, a member of this group, uses the term "our colony" to refer to his social circle which included himself, a journalist; Nick Walsh, a painter; Captain Bingham, a soldier and correspondent of the Pall Mall Gazette; and John Mitchell (John Augustus O'Shea, Leaves from the Life of a Special Correspondent, London, Ward \& Downey, 1885, vol. I, p. 6-9). Janick Julienne offers a good overview of the Irish Colony in her biography of its most energetic member, John Patrick Leonard (Janick Julienne, "John Patrick Leonard and the Irish Colony in Paris", in Paris, Capital of Irish Culture: France, Ireland and the Republic, 1798-1916, Pierre Joannon, Kevin Whelan (eds.), Dublin, Four Courts Press, 2017, p. 145-159), while a good contemporary overview is to be found in "The Irish Colony in Paris", The Brisbane Courier, 11 June 1884, p. 3. To further complicate the issue, the Irish Colony are often discussed in contrast to the Anciens Irlandais, those of Irish descent living in France. Julienne makes an effort to disentangle these two groups (Janick Julienne, "La France et l'Irlande nationaliste de 1860 à $1890 \ldots$.., p. 124-125). For further clarity, in this paper, the term "Fenian" is used to apply to those Irish nationalists who were directly involved with the movement (even if they were never officially sworn in to either the Fenian Brotherhood or the Irish Republican Brotherhood), while the phrase "the Irish Colony" is used to refer to Irish diaspora members living and working in France who had tangential links with the movement, if any at all. Not every member of the Irish Colony was allied with the Fenians, but the Fenians made good use of the Irish Colony to further their agenda in Paris.

6. See for example Pierre Joannon, "Paris: The Promised Land?", in Paris, Capital of Irish Culture..., p. 22-23. 
role played by this Irish diasporic community within Paris. Finally, it will also assess how exactly the Fenians were influenced by continental societies while in Paris, highlighting what they actually learnt from these groups.

\section{Anglo-French relations and the Fenians}

The importance of Anglo-French relations to the formation of the Fenian movement and to their operations in Paris cannot be understated. Indeed, Richard Comerford makes the strong argument that, far aside from any other factor, the Fenian movement most prominently had its roots in the shape of international diplomacy in the middle of the $19^{\text {th }}$ century. He writes that, "Stephens and his collaborators were responding not to a domestic but to an external (and fortuitous) stimulus - a crisis in AngloFrench relations". ${ }^{7}$ Although France and Britain had been fighting on the same side against Russia in the Crimean War, tensions between these two neighbours rose in the wake of this conflict. This was largely the result of France's conduct in the years following the war: Napoleon III continued to maintain a large standing army, and began embarking on the expansion and modernisation of the French navy to the point where it could threaten the Royal Navy. ${ }^{8}$ This crisis in international relations was further exacerbated by the Franco-Austrian War of 1859. Although this latter conflict largely concerned Italy and Franco-Austrian relations, it was nonetheless the belief of many in Ireland that war between France and England would soon follow. ${ }^{9}$ Tellingly, Stephens, in a letter later reflected that, "Hope, not to say faith came with the Italian campaign". ${ }^{10}$ At this point in the $19^{\text {th }}$ century, Europe to international observers, particularly those in Ireland, seemed to be a powder keg. Even the abrupt cessation of hostilities between France and Austria with the Treaty of Villafranca in July 1859, after no more than a few months of conflict, did little to disperse the idea that war between Britain and France was imminent and inevitable. ${ }^{11}$

In Ireland, the deterioration of Anglo-French relations was seen as heralding the nation's moment of opportunity. ${ }^{12}$ France, as a rival power on a par with Britain, was a key factor for anyone hoping to disrupt British dominion over Ireland. ${ }^{13}$ Irish

7. Richard Comerford, "Anglo-French Tensions and the Origins of Fenianism", in Ireland under the Union: Varieties of Tension. Essays in Honour of T. W. Moody, F. S. L. Lyon, R. A. J. Hawkins (eds.), Oxford, Clarendon Press, 1980, p. 149.

8. Richard Comerford, The Fenians in Context: Irish Politics and Society, 1848-82, Dublin, Wolfhound Press, 1998, p. 43-44.

9. William Dillon, Life of John Mitchel, London, Kegan Paul, Trench \& Co., 1888, vol. II, p. 131-134.

10. Letter from James Stephens concerning international affairs, National Library of Ireland, Ms. 10,492/2. The letter itself is undated, but it is included within a collection of other letters, many of which are from the 1870s. Judging from the context within the letter and the other letters in the collection, it is likely to originate from 1874.

11. Richard Comerford, “Anglo-French Tensions...", p. 156.

12. Richard Comerford, The Fenians in Context..., p. 45.

13. Richard Comerford, "France, Fenianism and Irish Nationalist Strategy", Études irlandaises, no. 7, 1982, p. 115, online: https://www.persee.fr/doc/irlan_0183-973x_1982_num_7_1_2675. 
nationalists were very much aware that Ireland represented a strategic threat to Britain, and that France may invade the country in the hopes of wounding Britain. ${ }^{14}$ The beginnings of the Fenian movement are, thus, very much linked to this threat of war between Britain and France in the 1850s, and the hope that France would seek to strike at Britain through Ireland. ${ }^{15}$ There was not always agreement as to whether France would do this in Ireland's interests or purely its own, but the threat was nonetheless very clear. Indeed, although there was debate within the Fenian cause as to whether France should be encouraged to invade Ireland or not, both sides nonetheless agreed that friendly relations between Irish nationalists and the French government were desirable. ${ }^{16}$ This reflects a wider belief, central to the Fenian movement in the middle of the $19^{\text {th }}$ century, that Ireland's fortunes were tied directly to those of France. ${ }^{17}$ That France might declare war on Britain, and attempt to wound Britain by invading Ireland, was a key factor for many of those seeking to join the rank and file of the Fenians. ${ }^{18}$

More importantly, for the Fenian organisers this centrality of France to a potential European conflict involving Britain made Paris a city of key strategic importance. The Fenians believed that, because they too were enemies of Britain, they would be able to approach the French government as natural allies. Stephens, for example, despite having left France in 1855 returned to Paris again in 1859 sometime just before the Franco-Austrian War, at a moment when the crisis in Anglo-French relations was at its starkest. Stephens hoped to be in a position to present himself to the French administration as a useful ally when war between these nations finally erupted. ${ }^{19}$ Furthermore, though his connections to the Fenian movement are tenuous, John Mitchel similarly arrived in Paris around the same time as Stephens, and largely for the same reason. ${ }^{20}$

At this point in time, both concentrated their efforts on disrupting the then-extant but rapidly deteriorating Anglo-French alliance, and although neither were particularly successful, their efforts nonetheless highlight the importance of the wider diplomatic context to Fenian affairs. ${ }^{21}$ Stephens himself expressed regret at not being able to seize the chance and blamed a lack of funds, rather any necessary incompatibility between Irish and French sentiments, for his lack of success. ${ }^{22}$ Indeed, even once Anglo-French tensions had most definitively been

14. John Martin, William Smith O’Brien, Correspondence between John Martin and William Smith O'Brien, Relative to a French Invasion, Dublin, J. O’Daly, 1861, p. 4.

15. Richard Comerford, "France, Fenianism and Irish Nationalist Strategy", p. 118.

16. John Martin, William Smith O'Brien, Correspondence between John Martin and William Smith O’Brien..., p. 3.

17. Máire Corkery, "Ireland and the Franco-Prussian War", Études irlandaises, no. 7, 1982, p. 128, online: https://www.persee.fr/doc/irlan_0183-973x_1982_num_7_1_2676.

18. Richard Comerford, “Anglo-French Tensions...", p. 153.

19. Ibid., p. 155.

20. William Dillon, Life of John Mitchel, p. 131-134.

21. Marta Ramón, A Provisional Dictator: James Stephens and the Fenian Movement, Dublin, University College Dublin Press, 2007, p. 100; William Dillon, Life of John Mitchel, p. 134.

22. "Letter from James Stephens Concerning International Affairs". 
diffused, many of the Fenians and the so-called "French Party" in Ireland - those who were particularly in support of a French invasion of the country - continued to argue that a conflict between Britain and France was inevitable. ${ }^{23}$ Even though the tensions between France and Britain never manifested in any useful way for Irish nationalists, the hope that war would shortly erupt is of key importance to understanding the Fenian movement in the $19^{\text {th }}$ century. Not only did the international scene make France a key piece in the grand scheme towards Irish liberation, but its wider diplomatic relations were also a principal factor in many of the Fenians choosing to operate in Paris.

\section{The MacMahon Sword Movement}

Indeed, perhaps the greatest example of the place of prominence France held in the minds of Irish nationalists is the so-called MacMahon Sword Movement. During the Franco-Austrian War, Patrice de MacMahon led his troops to a triumphant victory at the Battle of Magenta, which saw him raised to the titles of Marshal and Duke. Significantly, MacMahon was of Irish descent, and his victory led directly to his representation in Ireland as the personification of Franco-Irish amity. ${ }^{24}$ MacMahon's victorious campaign greatly excited Francophile Irish nationalists, some of whom even suggested that MacMahon would be a suitable candidate for an Irish monarch. ${ }^{25}$ This in turn led to the formation of the MacMahon Sword Committee and the beginning of the MacMahon Sword Movement, the purpose of which was to present MacMahon with a gift from the Irish people to celebrate his triumphant victory: in this case a beautifully engraved sword, which would be paid for by subscriptions from the Irish public. ${ }^{26}$ Although the movement masqueraded as a passive one, the intent of which was merely to honour MacMahon, it was very clearly political in nature. The MacMahon Sword Movement was, naturally, heavily connected to the international context and the hope that the French could be persuaded to invade Ireland, and that the threat of such invasion would force concessions from Britain. ${ }^{27}$ Indeed, William Smith O’Brien makes it clear that the purpose of the MacMahon Sword Committee was not merely to "do honor to Irish genius, or to Irish valour",

23. Richard Comerford, "Anglo-French Tensions...”, p. 166; the term "French Party" is employed by William Smith O’Brien in John Martin, William Smith O’Brien, Correspondence between John Martin and William Smith O'Brien... to refer to those individuals eager for a French invasion of Ireland. He does not specify directly who is included within the French Party, but does refer to the "course taken by some of the Irish journals" (p. 3). In addition, he criticises the "policy advocated by the subscribers to the MacMahon sword" (p. 5). The MacMahon Sword Movement which O'Brien refers to here was orchestrated in no small part by The Nation, and consequently we can take it that The Nation and its readership are chief among the "French Party".

24. Richard Comerford, “Anglo-French Tensions...”, p. 157-158.

25. Richard Comerford, The Fenians in Context..., p. 58-59; as with the "French Party" discussed earlier, the most common proponents of this kind of sentiment are found situated around The Nation.

26. “A Gift for Marshal MacMahon from the Irish Nation”, The Nation, 2 July 1859, p. 9.

27. Marta Ramón, A Provisional Dictator..., p. 106. 
but rather to be "an intimation that MacMahon would be welcome here at the head of a French army”. ${ }^{28}$ O'Brien even goes so far as to note, somewhat dismissively, that "Irish people are encouraged to look upon MacMahon as the future King of Ireland". ${ }^{29}$

Though the MacMahon Sword Movement generated few tangible results, it highlights the eagerness with which Irish nationalists met news of French victories, and their hopes that France could be encouraged to support their efforts. Not only this, but the movement is also important because it highlights the distinct role played by the Irish Colony in this period. The Irish Colony, as the principle Irish diasporic community in Paris at this time, formed the backdrop to Irish affairs in France. Indeed, as a notably politically active community, the Colony was especially an asset to the Fenians in Paris, and frequently appears in Fenian memoirs of exile in the city. Notably, its involvement in the MacMahon Sword Movement underscores the kind of activity which was typical of this diasporic community. The involvement of the Irish Colony in the movement demonstrates that it was alive to movements back in Ireland, and may have even offered a window into these for the Fenian exiles.

The Irish Colony was heavily involved in this movement from the outset. In describing the setting up of the fund and the subscription for the sword, The Nation writes that "we have laid before some of the best Irishmen at home and in other countries the proposition that a national subscription be set on foot" ${ }^{30}$ Given that the only other country in which the Irish diaspora would have a significant stake in the movement was France, it is only reasonable to assume that this refers principally if not exclusively to the Irish Colony, indicating an involvement from the very beginning of the movement. Indeed, one of the Colony's most active members, John Patrick Leonard, seems to have been heavily invested in the movement, and continually appears throughout its planning, organisation and conclusion. John Devoy describes Leonard simply as "correspondent of The Nation in Paris", however Leonard was much more significant than such a description would suggest. ${ }^{31}$ Leonard spent the majority of his life, from 1834 until his death in 1889, in France, and his influence can be seen in many of the activities of the Irish Colony in this period. ${ }^{32}$ In this case, The Nation indicates that Leonard was interested in the programme to bestow the honour on Marshal MacMahon "some weeks before any allusion to a MacMahon Testimonial was made public in any newspaper". ${ }^{33}$ Furthermore, as the MacMahon Sword Committee formed, it was thought to seek the Marshal's consent before any moves were made. It was none other than Leonard himself who ultimately approached the Marshal on this matter. ${ }^{34}$ Perhaps most significantly, when the time came to

\footnotetext{
28. John Martin, William Smith O’Brien, Correspondence between John Martin and William Smith O’Brien..., p. 5.

29. Ibid.

30. “A Gift for Marshal MacMahon from the Irish Nation", p. 9 (our italics).

31. John Devoy, Recollections of an Irish Rebel: A Personal Narrative by John Devoy, New York, Chas. P. Young Company, 1929, p. 273.

32. For an overview of Leonard's life and his activities, see Janick Julienne, "John Patrick Leonard...".

33. "MacMahon Testimonial - Report", The Nation, 27 August 1859, p. 14.

34. Richard Comerford, “Anglo-French Tensions...”, p. 158.
} 
actually present the sword to the Marshal, Leonard accompanied the deputation sent from Ireland to the ceremony. ${ }^{35}$

Leonard was, therefore, very much an asset to the MacMahon Sword Movement, and his involvement highlights the connections between the Irish Colony and political movements in Ireland more generally. Leonard allowed the movement a contact not only in Paris, but one close to the Marshal himself, and he was clearly responsible for helping bring the project to fruition. ${ }^{36}$ Indeed, The Nation describes Leonard as

[...] a valued friend in that city [Paris], whose heart has ever been true to the green island

$[\ldots]$ and from whose ever active mind and vigorous intellect Irish national movements have long been accustomed to receive faithful and valuable aid $[\ldots]{ }^{37}$

Taken by itself, the Irish Colony's involvement in the MacMahon Sword Movement might be seen as a personal project of Leonard's. However, it is clear that Leonard is representative of the Irish Colony as a whole, even if he was perhaps its most active individual. For example, the Committee formed to organise the movement counted amongst its members not only "John P. Leonard, Paris" but also "Colonel Byrne, Paris". ${ }^{38}$ Colonel Miles Byrne was a member of the old United Irishmen stock in Paris, and his involvement in the movement indicates that Leonard was not some anomaly in the community.

For the Fenians, this kind of political activity was highly significant. Although the Irish Colony was not always directly involved in the Fenian movement itself, the politically active nature of the community was doubtless an asset to those who found themselves in Paris. Leonard's links with MacMahon, for example, and his ability to call on him to seek his consent, show that the community was highly connected and enjoyed connections which the Fenians could potentially make use of. Though, as Ramón notes, it was not always easy to fully engage the Irish Colony in plans of the Parisian Fenians, they were nonetheless a factor which could be incorporated into their schemes. ${ }^{39}$

\section{The secret societies of Paris}

Indeed, the political activity of the Irish Colony highlights character of Paris in the mid- $19^{\text {th }}$ century. At this time, Paris played host to a variety of exiled nationalists, with whom the Franco-Irish diaspora - the Irish Colony generally and the Fenian exiles in particular - were in contact. Of particular note here are those local and exiled nationalists who formed the core of the Parisian secret societies such as La Société

35. Richard Comerford, “Anglo-French Tensions...”, p. 159.

36. “MacMahon Testimonial - Report”, p. 14.

37. Ibid.

38. Ibid

39. Marta Ramón, A Provisional Dictator..., p. 51-52. 
des Saisons, Young Italy and Young Poland. ${ }^{40}$ Although Paris would greatly influence all of the Fenians who passed through it, those who were most directly influenced by the revolutionary methods of the city's secret societies were James Stephens and John O'Mahony. ${ }^{41}$ However, there is some debate as to the extent to which the Fenians were influenced by these groups. ${ }^{42}$ Much of the uncertainty in this regard seems to stem from a contemporary assertion that Stephens and O'Mahony were not only initiated into Parisian societies similar in character to their own later societies, but that they rose to prominence in them. ${ }^{43}$ A contemporary biography of Stephens' denies this claim, writing "this assertion is not true. While [Stephens] lost no opportunity in familiarising himself with the revolutionary leaders, and the principles and ideas which they advanced, he never was initiated into any of the secret societies". ${ }^{44}$ In a contemporary account from only two years later, John Savage contests this, and while he does not suggest that Stephens and O'Mahony reached a high rank in these other societies, he nonetheless suggests that they did join them. In particular, he writes that, at the time of their exile in Paris, the city was filled with secret societies who had "peculiar fascinations for those whose former attempts at rebellion had proved failures, simply for the want of previous organisation of the revolutionary elements". ${ }^{45}$ Savage seems to hold that, because of this, Stephens and O'Mahony were able to enroll as "pupils of some of the ablest masters of revolutionary science which the $19^{\text {th }}$ century has produced". ${ }^{46}$ Ultimately, Savage was likely seeking to embellish his account of Stephens and O'Mahony's time in Paris rather than provide a fully accurate assessment of their exile. ${ }^{47}$ Comerford, like the anonymous author of Stephens' biography, ardently denies Savage's claim, pointing out that

40. Although this paper focuses primarily on these groups, it is of course worth noting that other secret societies were present in Paris at this time. For example, Young Italy were not the only Italian diaspora group present in Paris, the Carbonari were also present in the city. See Niall Whelehan, The Dynamiters: Irish Nationalism and Political Violence in the Wider World, Cambridge, Cambridge University Press, 2012, p. 47-48.

41. In this case, their period of exile was from 1848-1855 for Stephens, and 1848-1853 for O'Mahony. Although it has been noted before that Stephens would consistently return to Paris in the following decades, this initial period of exile was when he learnt the most from the other exile revolutionaries.

42. For example, John Savage's contemporary account claims that the only thing Stephens and O'Mahony failed to learn from the Parisian revolutionary societies was the methods by which treason and insubordination could be prevented (John Savage, Fenian Heroes and Martyrs, Boston, P. Donahoe, 1868, p. 307), while Comerford casts significant doubt on this claim (Richard Comerford, "France, Fenianism and Irish Nationalist Strategy", p. 119).

43. Richard Comerford, The Fenians in Context..., p. 39. The societies Stephens and O'Mahony supposedly joined are not usually named in the literature - Leon Ó Broin for example simply describes them as "French underground societies" (Leon Ó Broin, Revolutionary Underground: The Story of the Irish Republican Brotherhood, 1858-1924, Dublin, Gill and Macmillan, 1976, p. 2).

44. James Stephens, Chief Organizer of the Fenian Brotherhood, New York, Carleton, 1866, p. 39.

45. John Savage, Fenian Heroes and Martyrs, p. 306-307.

46. Ibid.

47. Further casting doubt on Savage's claims, he fails to name the societies in question, and gives no further detail concerning them other than to describe them as "masters of revolutionary science" (ibid.). 
[...] scarcely anything put on record by Stephens or O'Mahony amounts to convincing evidence that they were initiated into any continental secret society, and even if they were, it is virtually certain that they never advanced beyond the lower ranks. ${ }^{48}$

Marta Ramón similarly writes that "there is very little evidence to sustain" the theory that O'Mahony and Stephens joined any secret societies during the early years of their exile. ${ }^{49}$

With all that said, however, it is clear that the early Fenian planners did, at least to some extent, learn and take inspiration from the Parisian revolutionary societies, even if they did not join their ranks. The question therefore remains: what exactly did Stephens and O'Mahony learn during their time in Paris? Ramón notes that it is unclear how much Stephens' organisation of the IRB drew from continental conspiracies, how much from the Irish tradition of secret societies and how much from his own mind. Nevertheless, she does point out that Stephens claimed to draw from Giuseppe Mazzini and continental societies, and even notes that "there are certain similarities in [Stephens and Mazzini's] political thought, such as their notions of virtue and sacrifice or the principle of self-reliance in the struggle for national liberation". ${ }^{50}$ She also writes that, while it is difficult to say for certain exactly where Stephens and O'Mahony gained their advanced republican convictions, Paris was nonetheless the source of the "transformation of the rebel into the revolutionary". ${ }^{51}$ Indeed, this would fit with the wider trend of European revolutionary exiles in the $19^{\text {th }}$ century. For example, John Burrow describes how "Russians and Germans went to Paris, up to the end of the 1840 s to breathe a freer political air and learn about revolution and the contours of forthcoming utopias". ${ }^{52}$ Ramón more or less applies this thesis to the Fenians, arguing that Paris offered the perfect environment to nurture their change from rebels into revolutionaries, not only because of the expected effects of exile, but also because of their experience of life under a republican regime and frequent contacts with Parisian republicanism. ${ }^{53}$

It may be impossible to say for certain exactly from where Stephens and O'Mahony drew their revolutionary inspiration, but it is likely not a coincidence that the developments in their thought and the new ideas for organising the IRB formed during their time in Paris, where they were most closely exposed to similar continental societies. By comparing the IRB with the ethos and methods of the

48. Richard Comerford, The Fenians in Context..., p. 39.

49. Marta Ramón, A Provisional Dictator..., p. 58.

50. Ibid., p. 81. Indeed, Nick Carter directly describes the IRB as "a Mazzinian-style nationalist organisation" (Nick Carter, "Introduction: Britain, Ireland and the Italian Risorgimento", in Britain, Ireland and the Italian Risorgimento, Nick Carter (ed.), New York, Palgrave Macmillan, 2015, p. 9).

51. Marta Ramón, A Provisional Dictator..., p. 57-58.

52. John Burrow, “A Common Culture?: Nationalist Ideas in $19^{\text {th }}$-Century European Thought”, History of European Ideas, vol. 32, no. 3, 2006, p. 335; here, Burrow is primarily talking about members of Young Russia and Young Germany - that is to say, members of the cosmopolitan nationalist movement Young Europe.

53. Marta Ramón, A Provisional Dictator..., p. 57-58. 
various continental societies Stephens and O'Mahony may have encountered, it is possible to conjecture which groups likely influenced the early Fenians and how. In this regard, there are three principal societies worth considering: the Paris-based La Société des Familles / La Société des Saisons, Mazzini's Young Italy, and the related Young Poland. ${ }^{54}$ It is generally agreed that Stephens' ultimate conception of the IRB was based on a synthesis of the thinking of a variety of revolutionary societies, and thus no one group can be said to be the chief influence upon the IRB. ${ }^{55}$ As such, it is worth examining each of the groups noted above, highlighting their possible influences on the Fenians.

\section{La Société des Saisons and French republicanism}

As with all the groups addressed here, Les Saisons are more complex than can be easily summarised in a short article. However, in brief they were comprised of those who were dissatisfied by the outcomes of the July Revolution, and their objective was to overthrow the French monarchy. ${ }^{56}$ With regards to the Fenians, one aspect of their organisation is particularly significant: their cellular structure. In La Société des Familles, secrecy was ensured by organising the society so that each member only knew their immediate officer and the other members of their cohort, and not any of their superiors or any other members outside of their cohort. When Les Saisons was formed, the strict demands of secrecy were relaxed somewhat, but the cellular structure remained. In Les Saisons the organisation was as follows: six members led by a "Sunday" formed a "Week"; four "Weeks" commanded by a "July" constituted a "Month"; three "Months" were commanded by a "Spring" or a "Season"; and four "Seasons" were led by a "Revolutionary Agent". ${ }^{57}$ This structure, though exceedingly dramatic in its nomenclature, is distinctly similar to that adopted by the IRB, whereby nine "Ds" were led by a "C"; nine "Cs" were in turn led by a " $\mathrm{B}$ "; and nine "Bs" were then led by an "A", who constituted the "Centre" of a given "Circle". ${ }^{58}$ In the IRB, as in Les Saisons, the intention was that any given " $D$ " would only know the other "Ds" in their circle and their commanding "C" - not anyone outside of that - and so on up the structure. It is unclear whether these similarities in organisation were intentional or coincidental, however it is worth noting that in 1848 , the descendants of Les Saisons were again active in Paris, playing a crucial role in the revolution that

54. La Société des Familles and La Société des Saisons are placed side-by-side here because the former would become the latter in 1836, and both shared a similar structure and agenda. Henceforth, unless otherwise stated both groups will be referred to under the catch-all term, "Les Saisons", which they were themselves often called.

55. Marta Ramón, A Provisional Dictator..., p. 61; Richard Comerford, The Fenians in Context..., p. 47-48.

56. John Heron Lepper, Famous Secret Societies, London, Sampson Low, Marston \& Co., 1925, p. 174176.

57. Ibid., p. 175-176.

58. John O'Leary, Recollections of Fenians and Fenianism, London, Downey \& Co., 1896, vol. I, p. 84. 
year, and continuing to plot even after the establishment of the provisional government. ${ }^{59}$ Thus, Les Saisons - or at the very least, adherents of Les Saisons' structure and agenda - were active in Paris during Stephens and O'Mahony's informative exile there, possibly opening them up to that society's influence.

\section{Young Italy and Italian nationalism}

Young Italy is perhaps the most likely root of many of the continental-inspired aspects of the IRB's organisation and structure. ${ }^{60}$ Stefano Recchia and Nadia Urbinati describe Mazzini as "among the most influential European public figures of the mid $19^{\text {th }}$ century" ${ }^{61}$ and note that he "inspired several patriotic and anticolonial revolutionary movements in different parts of the world well into the twentieth century". ${ }^{62}$ Italy and Italian nationalism held a prominent though troubled position in Irish nationalist thought in this period. Although there were notable similarities between Ireland and Italy, the anti-clericism expressed in Italian nationalism, and Italian nationalism's hostility to the Papal States set many Irish Catholic nationalists against it, especially during the Risorgimento in the $1860 \mathrm{~s} .{ }^{63}$ Nonetheless, despite the antipathy of Irish Catholic nationalists towards Italian nationalism, links with secular Irish nationalism and Protestant Irish nationalism were more positive. These positive links date back to the Young Ireland movement, many of the adherents of which admired Mazzini directly. ${ }^{64}$ Nick Huggins, for example, notes that the "most important voices" of Young Ireland "empathised with and admired the Italian, most significantly during the formative period of radical Irish nationalism in the 1840s: there was, in other words, an ideological connection between Young Ireland and Young Italy". ${ }^{65}$ Indeed, even in the mid-1840s, a sense of internationalism

59. John Heron Lepper, Famous Secret Societies, p. 178.

60. Young Italy was formed in Marseille in 1831 by Mazzini, and from Marseille he orchestrated the profusion of the society throughout Italy. Mazzini had previously been a member of the Carbonari, but found their aims to be vague and indefinite. Young Italy was established with the aim of encouraging the union and independence of Italy in a republican form of government through a wide-ranging secret society. Young Italy spawned a wider "Young Europe" movement in 1834, from which emerged Young Poland, whose aims and modus operandi were similar to that of Young Italy's, though naturally concerning Poland's particular situation. Though it is a bit vague in places, John Heron Lepper, in Famous Secret Societies, p. 157-166, offers a good overview of Young Europe, especially Young Italy and Young Poland.

61. Stefano Recchia, Nadia Urbinati, "Preface", in A Cosmopolitanism of Nations: Giuseppe Mazzini's Writings on Democracy, Nation Building, and International Relations, Stefano Recchia, Nadia Urbinati (eds. and trans.), Princeton, Princeton University Press, 2009, p. vii.

62. Ibid.

63. Anne O'Connor, “That Dangerous Serpent: Garibaldi and Ireland 1860-1870”, Modern Italy, vol. 15 , no. 4, 2010, p. 403-404.

64. Despite being called "Young Ireland", the Young Irelanders had little direct connection with Mazzini's "Young Europe" movement, and the name was actually given to the Young Irelanders as a derogatory title.

65. Michael Huggins, "A Cosmopolitan Nationalism: Young Ireland and the Risorgimento", in Britain, Ireland and the Italian Risorgimento, p. 35. 
amongst Irish nationalists is evident: when the Poles revolted against Austria in 1846, The Nation demanded that Mazzini and the Young Italians also rise up to occupy the Austrians further, and a few months later the paper issued a call for Italy, Ireland and other nations to join together into an alliance against despotism. ${ }^{66}$ This demonstrates an awareness amongst Irish nationalists of other continental nationalists, even before the failure of the 1848 Rebellion scattered some exiled nationalists to the continent.

Furthermore, as has already been noted, Stephens himself claimed to be drawing on Mazzini's ideas when forming the IRB. Crucially, however, Mazzini was never in Paris. While it may be true that Stephens drew on Mazzini directly, it can hardly be said to be an aspect of the influence of Paris upon him directly, although the city may have made him more amenable to continental influence of this kind. However, Mazzini's absence from Paris does not rule out the possibility of Stephens and O'Mahony having contact with Young Italy while in exile, as many of the members of that organisation were present in the city. Reflecting later on his early exile in Paris, Stephens himself directly wrote that he made

[...] a particular study of continental secret societies, and in particular those which had ramifications in Italy; for Italians have in a certain way perfected conspiracy, and I thought that with certain reserves they were the best models to follow. ${ }^{67}$

Indeed, there is some evidence for interactions between Irish exile diaspora members and Italian exile diaspora members. For example, a member of the Irish Colony, William O'Donovan, met a brother of the prominent Italian nationalist Felice Orsini while he was briefly in the quarter of Paris designated for political exiles. ${ }^{68}$ Even more directly, while in Paris, Stephens engaged to learn Italian from some Italian revolutionary exiles also resident in the city, possibly allowing him to form a direct connection with Italian republicanism. ${ }^{69}$ The most notable Italian exile in this case was General Guglielmo Pepe, a leading member of the Neapolitan Carbonari who had been involved during the 1820 revolt in Naples. In particular, Niall Whelehan notes that, "given [his] experiences, Pepe might have imparted much to Stephens on the techniques of conspiracy". ${ }^{70}$ While Orsini and Pepe were members of the Carbonari, not Young Italy, that members of the Irish diaspora had direct connections vaunted Italian nationalists nonetheless establishes a precedence for such interactions in Paris.

Indeed, just as there are similarities between the IRB and Les Saisons, there are similarities between the modus operandi of the IRB and Young Italy. The intention for Young Italy was for the central committee of the society, based in Marseille - or anywhere else outside of Italy -, to direct the general effort of

\footnotetext{
66. Ibid., p. 39-40.

67. Quoted in Niall Whelehan, The Dynamiters..., p. 41.

68. John Augustus O'Shea, Leaves from the Life of a Special Correspondent, p. 95.

69. Marta Ramón, A Provisional Dictator..., p. 60.

70. Niall Whelehan, The Dynamiters..., p. 41-42.
} 
the Italian unification movement, while local committees in Italian cities would manage the specific details. ${ }^{71}$ Not only is this similar to the IRB notion of "centres" and "circles" operating from specific towns and cities in Ireland, it also has direct parallels with Stephens' orchestrating of the IRB from Paris. Although no formal "central committee" for the IRB was formed in this period, Stephens, with the aid of Thomas Clarke Luby and John O'Leary, for a time directed efforts in Ireland from his base in Paris. Furthermore, although he likely never encountered them directly, Stephens' leadership style - that of a "provisional dictator" with complete, almost autocratic control of the revolutionary movement - betrays similarities to the Italian revolutionary Giuseppe Garibaldi and the French revolutionary Louis Auguste Blanqui, both of whom styled themselves as provisional dictators and who Stephens would have likely studied during his time mingling with the revolutionary societies of Paris. ${ }^{72}$

\section{Young Poland and Polish nationalism}

The least discussed organisation in modern literature, and perhaps the least clear in its influence, is Young Poland, an offshoot of the Young Italy movement, and part of the larger "Young Europe" philosophy. ${ }^{73}$ Despite this lack of attention, the Polish exile diaspora was very prominent within Paris. R. F. Leslie, for example, notes that approximately 5,000 Polish exile émigrés made it to France following the collapse of the revolution in Poland in $1831 .{ }^{74}$ Significantly, both they and the Irish diaspora appear to have frequented similar locales. John Augustus O'Shea, in his retelling of the activities of the Irish Colony, offers an insight into the overlap between these two exile communities. He indicates that one of the crêmeries - la Crêmerie Revert - frequented by members of the Irish Colony, in particular Professor Mortimer, was also frequented by Polish exiles, and notes that it was "even said to have been the place of meeting of the first Polish convention in Paris". ${ }^{75}$ What is more, O'Shea writes that "nearly every one of the Poles to be encountered in the cremerie $[s i c]$ had served with distinction in the [Polish] insurrection". ${ }^{76}$ Indeed, judging from his writings, he appears to have known several of them on a more personal level. That O'Shea and Mortimer, members of the Irish Colony, were aware of, and evidently friendly with, the elements of Young Poland in Paris, opens up the possibility of Stephens and O'Mahony having similar relations, or at the very

71. John Heron Lepper, Famous Secret Societies, p. 158-159.

72. Niall Whelehan, The Dynamiters..., p. 47-48.

73. For example, Marta Ramón dedicates some time in A Provisional Dictator to discussing Mazzini and Young Italy, and Richard Comerford in The Fenians in Context alludes to Les Saisons, but neither address Young Poland.

74. R. F. Leslie, "Left-Wing Political Tactics in Poland, 1831-1846", The Slavonic and East European Review, vol. 33, no. 80, December 1954, p. 120.

75. John Augustus O'Shea, Leaves from the Life..., p. 88.

76. Ibid., p. 91. 
least being influenced by Young Poland through osmosis from the rest of the Irish Colony. Although it is more difficult to draw parallels between Young Poland's organisation and the IRB's, this potential connection is nonetheless significant as Young Poland had similar beliefs to Young Italy, having directly learnt from them. Thus, even if the Fenian planners drew nothing from Young Poland directly, they were nonetheless exposing themselves to more of the kind of revolutionary sentiment that was put forth by Young Italy.

Indeed, it would not be unreasonable to suggest there were connections between Irish and Polish émigrés in Paris because Irish nationalists were well aware of the struggles of Poland and of Polish nationalism. Even as early as the 1840 s, just as there was an awareness of Italy's plight in Irish nationalist thinking, there was also an awareness of the plight of Poland. For example, during the 1848 Revolutions on the continent and especially in France, French sympathisers with Ireland's struggle were cited in The Nation comparing Ireland's situation to that of Poland and Italy. ${ }^{77}$ More significantly, there was a clear sympathy for Poland expressed in Irish nationalist circles during the January Uprising in 1863-1864. Discussing the uprising, Róisín Healy writes that "not surprisingly, the Fenians expressed particular admiration for the Poles. At the same time, they exploited the Polish cause as a vehicle for their immediate priority - freedom for Ireland". ${ }^{78}$ The brutal suppression of the January Uprising further emphasised the parallels between Ireland and Poland as victims of oppression, and for Irish nationalists the aftermath of the 1863-1864 Uprising evoked memories of the aftermath of the 1798 Rebellion. ${ }^{79}$

The January Uprising saw widespread expressions of support for the Polish cause in Ireland, and one of the most significant of which from an Irish nationalist perspective was the lecture given by William Smith O'Brien on 1 July at the Rotunda. Smith O'Brien had been invited to speak by an invitation signed by sixty nationalists, and Healy notes that though he was disliked by the Fenians on account of his outright rejection of violence, nonetheless there is evidence to suggest there were Fenians present at the lecture. ${ }^{80}$ Smith O'Brien's lecture encouraged a large fundraising drive in Ireland which drew direct parallels between Ireland's situation and that of Poland. Indeed, one Joseph McCorry, writing to the editor of The Nation during the fundraising, notes that

[...] particularly at this time, when the clouds of revolution are looming in the distance, and no one can tell where they may burst first, it ill behoves Irishmen to slumber now, when they should have all their energies at work, in order to be ready for the first opportunity which may offer itself to us. ${ }^{81}$

77. Matthew Kelly, "Languages of Radicalism...," p. 805.

78. Róisín Healy, Poland in the Irish Nationalist Imagination, 1772-1922, Basingstoke, Palgrave Macmillan, 2017, p. 159.

79. Ibid., p. 160.

80. Ibid., p. 168-171.

81. "Help For Poland", The Nation, 2 January 1864. 
Nor is this fundraising drive notable merely because it demonstrates Irish nationalist awareness of Poland - it also offers direct evidence of connections between the Irish Colony in Paris and the Polish émigré community. The minutes of the Polish Committee of Ireland from 14 October indicate that John Patrick Leonard was a means of contact for the committee to the Polish émigrés in Paris. Leonard writes to the committee:

I had the honour of an interview with Prince Czartoryski [in Paris] to day, and handed him your letter containing 28l. He is most grateful for this proof of sympathy for Poland on the part of our countrymen. ${ }^{82}$

Thus, given Leonard's already notable influence within the Irish diaspora and within Irish political movements in France, combined with already established links with the Polish community such as in la Crêmerie Revert the notion that the Fenians may have also had links with the Parisian Polish émigrés does not seem impossible.

\section{The oath of the Irish Republican Brotherhood}

The influence of these societies on the IRB is evident not only in its organisation, but in the composition of its oath vis-à-vis the oaths of the other conspiracies. ${ }^{83}$ The oath of the IRB, in its original form, reads

I, A B, do solemnly swear, in the presence of Almighty God, that I will do my utmost, at every risk, while life lasts, to make Ireland an independent Democratic Republic; that I will yield implicit obedience, in all things not contrary to the law of God, to the commands of my superior officers; and that I shall preserve inviolable secrecy regarding all the transactions of this secretary society that may be confided to me. So help me God! Amen. ${ }^{84}$

Although the oath would later be altered slightly, this was the version created by Stephens immediately after his sojourn in Paris. There are some similarities between it and the oaths of Young Italy and Les Familles. ${ }^{85}$ Both the IRB oath and the Young Italy oath, for example, include a line whereby the adherents swear to dedicate themselves completely to the cause of liberating their respective nations. Young Italy's oath includes the line "To dedicate myself wholly and for ever to endeavour to constitute Italy one free, independent, Republican nation - to promote

82. “The Polish Committee of Ireland", The Freeman's Journal, 14 October 1864.

83. For the oath of Young Italy, see John Heron Lepper, Famous Secret Societies, p. 159; for the oath of Les Familles, see John Heron Lepper, Famous Secret Societies, p. 175; for the oath of Les Saisons see John Heron Lepper, Famous Secret Societies, p. 177.

84. John O'Leary, Recollections of Fenians and Fenianism..., p. 120-121.

85. To a certain extent, this may be problematic as it is comparing an English-language oath with an English-language translation of an oath that was, presumably, originally in Italian and French respectively. However, what is important here is not a word-for-word similarity, but rather a similarity in sentiment. 
by every means in my power", which is markedly similar to the sentiment expressed by the opening line of the IRB's oath: "I will do my utmost, at every risk, while life lasts, to make Ireland an independent Democratic Republic". Similarly, both oaths make the initiate swear to unflinchingly obey the orders of the superiors, and to keep secret any and all communications from those superiors. ${ }^{86}$ For oaths whose collective word count is less than 250 words, it is highly significant that they would share such similarities. Indeed, while there is no major overlap between the oath of Les Saisons and that of the IRB, the original oath of Les Familles, before it was revised when the society was reconstituted, did also share the demands of secrecy and obedience that are present in both the Young Italy and IRB oaths. ${ }^{87}$ As with all things relating to the influence of these societies on the Fenians, it most certainly could be merely circumstantial and coincidental. However, with the IRB sharing both similarities in its organisation and similarities in its oath with these continental societies, it seems likely that the Fenian planners gained at least something from them during their exile in Paris.

\section{Conclusion}

Paris in the $19^{\text {th }}$ century was of supreme importance to the Fenians in no small part because of its status as capital of the power Irish people believed was most set against the British Empire. That France seemed primed to strike a blow against Britain was a hugely important factor in the early formation of the IRB, and the subsequent use of Paris as a base for their operations. Indeed, the use of Paris was further encouraged by the presence of the Irish Colony in the city. As a highly active community with direct links to Ireland, the Irish Colony encouraged the Fenians during their exile, offering them contacts and connections. Throughout this period, the Irish Colony demonstrated, through movements such as the MacMahon Sword Movement, that it was highly influential not only with movements in Ireland, but also with key figures in French society.

Furthermore, Paris was the primary European city to which political exiles of all kinds were drawn, and this made it the ideal breeding ground for the new Fenian movement. Paris played host to both Italian and Polish exiles - countries whose nationalist struggle was well known in Ireland. Though there is only a patchwork of direct evidence demonstrating connections between these various European diasporas, it seems plausible that the early Fenians would have encountered similar nationalist exiles during their time in Paris. Consequently, the presence of other continental conspiracies of similar ideological and political orientation allowed the

86. "[...] to obey all the instructions in conformity with the spirit of Young Italy given me by those who represent with me the union of my Italian brothers [...]" and "[...] to keep the secret of these instructions, even at the cost of my life [...]".

87. "I swear never to reveal to anyone, not even to my nearest relative, what is said amongst us" and "I swear to obey the laws of the association [...]". 
early Fenian planners to synthesise their ideas when seeking to perfect their own organisation. Although it is difficult to say for certain what the Fenians directly drew from these societies, and what they created themselves, there are too many similarities between the IRB and the likes of La Société des Saisons, Young Italy and Young Poland to assert that there was no inspiration whatsoever. The most likely influence is in the cellular structure adopted by the IRB, which is present in many of these other organisations, but there are similarities too in the sentiments expressed in the IRB oath and in the oaths of these other societies. Therefore, Paris, and France more generally, were highly ideologically significant to the Fenian movement, and their importance to the Fenians cannot be understated. The direct influence of the Parisian societies on the Fenians must perhaps always remain unclear, but it nonetheless seems likely that in both structure and in oath the IRB borrowed to some degree from the conspiracies its organisers encountered.

Luke William WATsoN

University College Cork 